\title{
三叉神経領域の体性感覚誘発反応の臨床的研究
}

\author{
柳澤繁孝・清 水 正 嗣・明石喜久雄*・遠藤 秀樹* \\ 照屋 昇*
}

\section{The clinical study of somatosensory evoked potentials (SEP) caused by trigeminus nerve stimulation}

\author{
Shigetaka YANAgISAwa - Masatsugu Shimizu • Kikuo AkasI* \\ Hideki ENDo* • Noboru TERUYA*
}

\begin{abstract}
For the purpose of the clinical application of somatosensory evoked potential (SEP) as an objective examination, we studied the triggered mechanical stimulation on the trigeminus nerve region. The experiments were carried out with sixteen healthy adults ( 8 males and 8 females) from eighteen to twenty-four years old and seven patients who suffered from mandibular bone diseases. We applied tactile stimulation to the lower lip with a plastic bar. The trial was repeated forty times to get the summated evoked potential.

In the healthy group, SEP was characterized by ten peaks. Those were named $P_{1}$ (positive peak), $N_{1}$ (negative peak), through $N_{5}$. The latencies of those peaks were approximately 18 $\operatorname{msec}\left(P_{1}\right), 56 \mathrm{msec}\left(\mathrm{N}_{1}\right), 80 \mathrm{msec}\left(\mathrm{P}_{2}\right), 112 \mathrm{msec}\left(\mathrm{N}_{2}\right), 135 \mathrm{msec}\left(\mathrm{P}_{3}\right), 177 \mathrm{msec}\left(\mathrm{N}_{3}\right), 142 \mathrm{msec}$ $\left(\mathrm{P}_{4}\right), 285 \mathrm{msec}\left(\mathrm{N}_{4}\right), 334 \mathrm{msec}\left(\mathrm{P}_{5}\right)$ and $399 \mathrm{msec}\left(\mathrm{N}_{5}\right)$. The latency of $\mathrm{P}_{1}$ developed a tendency to be shortened by the magnitude of the stimulation. The amplitude of $\mathrm{P}_{1}-\mathrm{N}_{1}$ was $5.7 \mu \mathrm{V}$ with $1 / 8 \mathrm{~g}$ stimulation and $10.8 \mu \mathrm{V}$ with $1 / 2 \mathrm{~g}$ stimulation.

In the disease group, we recorded the SEP before and one month after the operation. At the preoperativ SEP, however sensory disturbances were not recognized, we noticed the abnormal findings which were an irregular wave and the delay of latency on the affected side. But there was no abnormality on the non-affected side. We acquired the results: the intraosseous lesions (ameloblastomas and mandibular cysts) that existed near the inferior alveolar nerve made the SEP's wave irregular and especially prolonged the latency of the $P_{1}$. These findings were also recognized in the hypoesthesia cases; the inferior alveolar nerve was affected by the operation and trauma. These findings increased with the up grading of the degree of hypoesthesia. In the case of sensory paralysis, we could not record an SEP wave.

Finally, we concluded that the SEP was a useful method to examine nerve disturbance in the trigeminus nerve region.
\end{abstract}

Key Words: somatosensory evoked potential (SEP), trigeminus nerve, mandibular lesion

大分医科大学畨科口腔外科

（主任：清水正硐教授）

* 東京医科歯科大学药学部第 1 口腔外科学講座 （主任：塩田重利教授）

Department of Dentistry and Maxillofacial Surgery, Medical College of Oita (Chief: Prof.
Masatsugu Shimizu)

* The first Department of Oral Surgery, Faculty of Dentistry, Tokyo Medical and Dental University (Chief: Prof. Shigetoshi Shioda)

受付日：昭和60年11月27日 


\section{I. 緒}

言

口腔外科の日常臨床において，外傷，炎症などの疾患 に合併した感覚障害および腫瘍，襄胞などの手術に継発 した感覚障害症例を経験することはまれではない，感覚 神経の障害では, 奇形, 腫瘍性病変, 襄胞, 炎症, 運動 神経 一筋などの疾患群とは異なり, 病状の他覚的所見を 得るのに困難がある。そのため, 病状の把握は患者の応 答に依存せざるを得ない，また，その表現は患者の性格 やインテリシェンスなどにも左右されることがあり，正 確な病状の把握と治療効果の判定に困難をきたすことも 少なくない。

近年では, 感覚の他覚的検查法として, 誘発反応の平 均加算法が視覚・聴覚・体性感覚については広く研究・ 臨床応用されている。体性感覚の誘発反応 (Somatosensory Evoked Potential 以下 SEP と記す) では主に正中 神経，尺骨神経あるいは座骨神経の電気刺激によって反 応を誘発し，記録している．三叉神経領域での報告は Spreng and Ichioka ${ }^{1)}$, Chatrian $5^{2)}$, 藤本 $5^{3)}$ ，およ び佐野 ${ }^{4)}$ が歯髄の電気刺激による SEP をまた，機械的

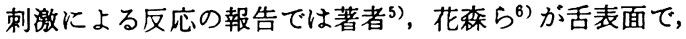
岡ら7)が顔面皮店の刺激によるものなどが散見される程 度である。

反応の誘発方法として，電気刺激あるいは機杵的刺激 のいずれかが用いられる。電気刺激は末梢神経を直接的 に興奮させるため time lag がきわめて少ない，しかし その半面刺激が必ずしも生理的なものとは言い難い，そ こでわれわれは自然な刺激（触刺激）による三叉神経領 域の SEP を記録・分析し, 感覚障害の他覚的検査法と して，その有用性について研究した。

\section{II. 実 験 方 法}

対象は18〜24歳までの健康男子 8 名, 健康女子 8 名の 正常群16名（32検索部位）と手術あるいは外傷による感 覚神経障害群 7 名 (14検索部位) である。

被験者および装置を図1のブロックダイフグムのご とく配置・接続した。被験者はシールドルーム内で仰 臥・安静・閉眼の状態においた。反応の導出には脳波用 皿電極 $(\mathrm{Ag}-\mathrm{AgCl})$ を使用し，大脳皮質の顔面部(三叉神 経）感覚領に近い側頭部（国際基準法 $\mathrm{T}_{3}$ お $^{\circ}$ よ゙ $\mathrm{T}_{4}$ ）に 探査電極を直き，基準電極を耳染におく単極導出法とし た，反応は日本光電社製ポリグラフ RM-85 で増幅し， 同社製加算解析装直 ATAC-250により40回加算ののち

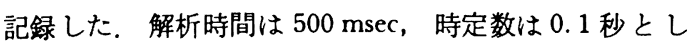
た.

刺激開始と同時に加算解析装置が作動するようにフォ トトランジスターを利用したトリガー回路を設直した。

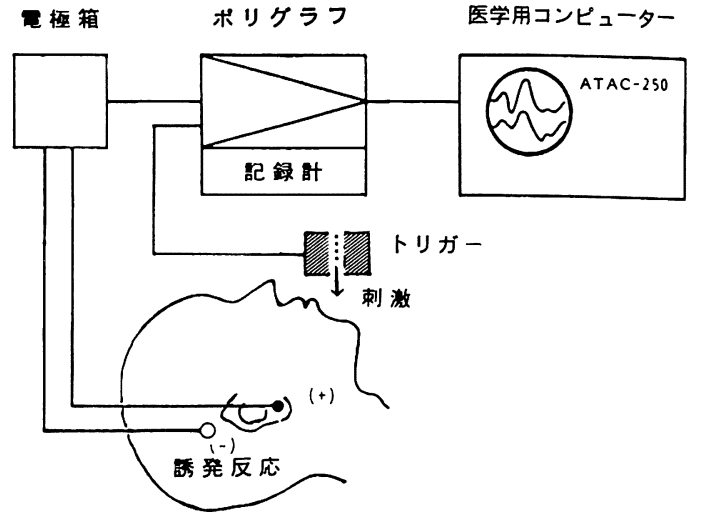

図 1 実験装置ブロックダイフグラム

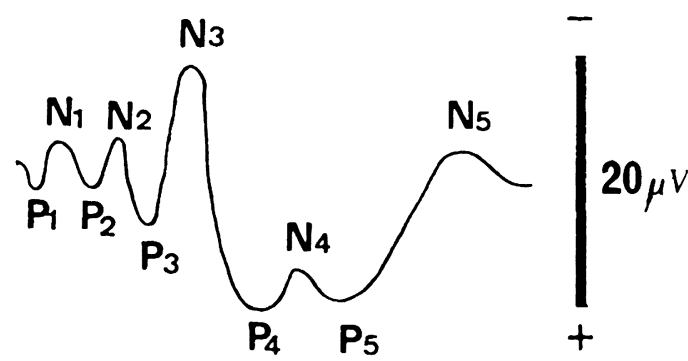

$\begin{array}{llll}100 & 200 \quad 300 \quad 400 & \mathrm{msec}\end{array}$

図 2 ヒトの三叉神経誘発反応 (SEP) の模型図

刺激には直径 $2 \mathrm{~mm}$, 重さ $1 / 8 \mathrm{~g}, 1 / 2 \mathrm{~g}$ および $2 \mathrm{~g}$ の樹 脂棒を下唇部皮店面より $20 \mathrm{~mm}$ 上方から落下させ，あ たえた。

実験中は脳波を持続的に観察し，脳波上で覚醒状態に あり, 眼球運動などのアーチファクトの混入しない時に 刺激を与えた。また，「慣れ」の影響をらけないように， 刺激間隔は10〜20秒の任意の時間とした。

SEP と背景脳波を区別するために，無刺激持の脳波 も同一条件で加算しここれら両者を比較し，検討に供し た.

SEP は，神経交叉があることから，刺激の反対側の 頭皮上から導出したものを主な分析の対象とした．潜伏 時間（潜持）は加算解析装置の作動時から波形の各頂点 までの時間を $4 \mathrm{msec}$ の間隔で測定し，求めた。なお リガーの作動時から皮店刺激にいたるまでの time lag の補正は行っていない，振幅（電位差）は頂点間の高さ (peak to peak) によって測定し, 理論上の加算効果, すなわち $\mathrm{n}$ 回加算によって振幅は $\sqrt{\mathbf{n}}$ 倍8) となる，に基 ついて算出した。 
表 1 SEP 各頂点の出現頻度 (\%)

\begin{tabular}{c|c|c|c|c|c|c|c|c|c|c|c}
\hline 刺激量 & 数 & $\mathrm{P}_{1}$ & $\mathrm{~N}_{1}$ & $\mathrm{P}_{2}$ & $\mathrm{~N}_{2}$ & $\mathrm{P}_{3}$ & $\mathrm{~N}_{3}$ & $\mathrm{P}_{4}$ & $\mathrm{~N}_{4}$ & $\mathrm{P}_{5}$ & $\mathrm{~N}_{5}$ \\
\hline $1 / 8 \mathrm{~g}$ & 16 & 81.3 & 87.5 & 93.2 & 75 & 87.2 & 100 & 93.8 & 81.3 & 87.5 & 87.5 \\
$1 / 2 \mathrm{~g}$ & 26 & 84.6 & 80.8 & 96.2 & 88.5 & 96.2 & 96.2 & 100 & 92.3 & 96.2 & 84.6 \\
\hline
\end{tabular}

表 2 SEP 各頂点の潜時

\begin{tabular}{|c|c|c|c|c|c|c|c|c|c|c|c|}
\hline 刺激量 & 数 & $P_{1}$ & $N_{1}$ & $\mathrm{P}_{2}$ & $\mathrm{~N}_{2}$ & $\mathrm{P}_{3}$ & $\mathrm{~N}_{3}$ & $\mathrm{P}_{4}$ & $\mathrm{~N}_{4}$ & $P_{5}$ & $\mathrm{~N}_{5}$ \\
\hline $1 / 8 \mathrm{~g}$ & 16 & $\begin{array}{l}24.7 \\
\pm 7.8\end{array}$ & $\begin{array}{l}56.7 \\
\pm 13.7\end{array}$ & $\begin{array}{l}83.8 \\
\pm 16.6\end{array}$ & $\begin{array}{l}119 \\
\pm 15.8\end{array}$ & $\begin{array}{l}136 \\
\pm 13.4\end{array}$ & $\begin{array}{l}177.4 \\
\pm 25.6\end{array}$ & $\begin{array}{l}233.8 \\
\pm 19.7\end{array}$ & $\begin{array}{l}283.1 \\
\pm 10.7\end{array}$ & $\begin{array}{l}321.4 \\
\pm 16.9\end{array}$ & $\begin{array}{c}379.9 \\
\pm 26.6\end{array}$ \\
\hline $1 / 2 \mathrm{~g}$ & 26 & $\begin{array}{l}18.0 \\
\pm 8.4\end{array}$ & $\begin{array}{l}56.2 \\
\pm 7.4\end{array}$ & $\begin{array}{l}80.0 \\
\pm 14.0\end{array}$ & $\begin{array}{l}112.2 \\
\pm 16.5\end{array}$ & $\begin{array}{c}135.2 \\
\pm 20.9\end{array}$ & $\begin{array}{l}177.4 \\
\pm 21.0\end{array}$ & $\begin{array}{c}242.6 \\
\pm 21.6\end{array}$ & $\begin{array}{l}285.3 \\
\pm 23.2\end{array}$ & $\begin{array}{l}333.6 \\
\pm 19.8\end{array}$ & $\begin{array}{l}398.9 \\
\pm 32.1\end{array}$ \\
\hline $2 \mathrm{~g}$ & 8 & $\begin{array}{l}17.2 \\
\pm 4.8\end{array}$ & $\begin{array}{l}49.6 \\
\pm 11.6\end{array}$ & $\begin{array}{l}65.2 \\
\pm 3.6\end{array}$ & $\begin{array}{c}107.2 \\
\pm 25.2\end{array}$ & $\begin{array}{c}128.8 \\
\pm 18.4\end{array}$ & $\begin{array}{l}171.2 \\
\pm 15.6\end{array}$ & $\begin{array}{l}230 \\
\pm 14.8\end{array}$ & $\begin{array}{l}257.2 \\
\pm 10.8\end{array}$ & $\begin{array}{l}316 \\
\pm 25.6\end{array}$ & $\begin{array}{l}368 \\
\pm 24\end{array}$ \\
\hline
\end{tabular}

(単位 $\mathrm{msec}$ )

表 3 SEP 頂点間の振幅（電位差）

\begin{tabular}{c|c|c|c|c|r|r|r|r|c}
\hline 刺激量 & \multicolumn{1}{c|}{$\mathrm{P}_{1}-\mathrm{N}_{1}$} & \multicolumn{1}{c|}{$\mathrm{N}_{1}-\mathrm{P}_{2}$} & \multicolumn{1}{c|}{$\mathrm{P}_{2}-\mathrm{N}_{2}$} & \multicolumn{1}{c|}{$\mathrm{N}_{2}-\mathrm{P}_{3}$} & \multicolumn{1}{c|}{$\mathrm{P}_{3}-\mathrm{N}_{3}$} & \multicolumn{1}{c}{$\mathrm{N}_{3}-\mathrm{P}_{4}$} & $\mathrm{P}_{4}-\mathrm{N}_{4}$ & \multicolumn{1}{c}{$\mathrm{N}_{4}-\mathrm{P}_{5}$} & $\mathrm{P}_{5}-\mathrm{N}_{5}$ \\
\hline $1 / 8 \mathrm{~g}$ & $5.7 \pm 1.3$ & $10.7 \pm 3.9$ & $9.9 \pm 6.3$ & $8.7 \pm 3.4$ & $15 \pm 5.6$ & $21 \pm 3.8$ & $5.1 \pm 1.5$ & $13.2 \pm 3.4$ & $17.3 \pm 6.5$ \\
$1 / 2 \mathrm{~g}$ & $10.8 \pm 3.7$ & $6.8 \pm 3.1$ & $10 \pm 5.8$ & $9.3 \pm 4.5$ & $11.9 \pm 3.9$ & $20.6 \pm 3.6$ & $11.5 \pm 5.5$ & $12 \pm 4$ & $15.9 \pm 6.3$ \\
\hline
\end{tabular}

(単位 $\mu \mathrm{V}$ )

表 4 各刺激量時の刺激側および反対側 SEP の頂点潜時

\begin{tabular}{|c|c|c|c|c|c|c|c|c|c|c|c|}
\hline & & $\mathrm{P}_{1}$ & $\mathrm{~N}_{1}$ & $\mathrm{P}_{2}$ & $\mathrm{~N}_{2}$ & $\mathrm{P}_{3}$ & $\mathrm{~N}_{3}$ & $\mathrm{P}_{4}$ & $\mathrm{~N}_{4}$ & $P_{5}$ & $\mathrm{~N}_{5}$ \\
\hline $1 / 8 \mathrm{~g}$ & 刺激側 & $\begin{array}{l}25 \\
\pm 10.2\end{array}$ & $\begin{array}{l}54.2 \\
\pm 14.5\end{array}$ & $\begin{array}{l}78.7 \\
\pm 12.7\end{array}$ & $\begin{array}{l}112.6 \\
\pm 16.8\end{array}$ & $\begin{array}{l}146.9 \\
\pm 23.3\end{array}$ & $\begin{array}{r}195.1 \\
\pm 145\end{array}$ & $\begin{array}{l}246.8 \\
\pm 21.3\end{array}$ & $\begin{array}{c}281.6 \\
\pm 18.3\end{array}$ & $\begin{array}{l}314.9 \\
\pm 15.7\end{array}$ & $\begin{array}{l}368 \\
\pm 26.3\end{array}$ \\
\hline $\begin{array}{l}\text { 剌 } \\
\text { 激 }\end{array}$ & 反対側 & $\begin{array}{l}24.7 \\
\pm 7.8\end{array}$ & $\begin{array}{l}56.7 \\
\pm 13.7\end{array}$ & $\begin{array}{l}83.8 \\
\pm 16.6\end{array}$ & $\begin{array}{l}119 \\
\pm 15.8\end{array}$ & $\begin{array}{l}136 \\
\pm 13.4\end{array}$ & $\begin{array}{l}177.4 \\
\pm 25.6\end{array}$ & $\begin{array}{l}233.8 \\
\pm 19.7\end{array}$ & $\begin{array}{l}283.1 \\
\pm 10.7\end{array}$ & $\begin{array}{l}321.4 \\
\pm 16.9\end{array}$ & $\begin{array}{l}377.9 \\
\pm 26.6\end{array}$ \\
\hline $1 / 2 \mathrm{~g}$ & 刺激側 & $\begin{array}{l}20.7 \\
\pm 7.9\end{array}$ & $\begin{array}{l}57.8 \\
\pm 10.9\end{array}$ & $\begin{array}{l}86.4 \\
\pm 14.3\end{array}$ & $\begin{array}{l}116 \\
\pm 16.8\end{array}$ & $\begin{array}{l}135.5 \\
\pm 17\end{array}$ & $\begin{array}{l}177.6 \\
\pm 21.9\end{array}$ & $\begin{array}{l}246.2 \\
\pm 20\end{array}$ & $\begin{array}{l}280 \\
\pm 25.6\end{array}$ & $\begin{array}{l}329.1 \\
\pm 19.2\end{array}$ & $\begin{array}{l}392.8 \\
\pm 23.8\end{array}$ \\
\hline $\begin{array}{l}\text { 刺 } \\
\text { 激 }\end{array}$ & 反対側 & $\begin{array}{l}18.0 \\
\pm 8.4\end{array}$ & $\begin{array}{l}56.2 \\
\pm 7.4\end{array}$ & $\begin{array}{l}80.0 \\
\pm 14.0\end{array}$ & $\begin{array}{l}112,2 \\
\pm 16.5\end{array}$ & $\begin{array}{l}135.2 \\
\pm 20.9\end{array}$ & $\begin{array}{l}174.4 \\
\pm 21.0\end{array}$ & $\begin{array}{l}242.6 \\
\pm 21.6 \\
\end{array}$ & $\begin{array}{l}285.3 \\
\pm 23.2 \\
\end{array}$ & $\begin{array}{l}333.6 \\
\pm 19.8 \\
\end{array}$ & $\begin{array}{l}398.9 \\
\pm 32.1\end{array}$ \\
\hline $2 \mathrm{~g}$ & 刺激側 & $\begin{array}{l}20 \\
\pm 5.2\end{array}$ & $\begin{array}{l}48 \\
\pm 10.8\end{array}$ & $\begin{array}{l}73.2 \\
\pm 5.2\end{array}$ & $\begin{array}{l}112.9 \\
\pm 19.6\end{array}$ & $\begin{array}{c}130.8 \\
\pm 17.6\end{array}$ & $\begin{array}{r}166.4 \\
\pm 8.4\end{array}$ & $\begin{array}{c}228.8 \\
\pm 14.4\end{array}$ & $\begin{array}{l}263.2 \\
\pm 52\end{array}$ & $\begin{array}{l}326.4 \\
\pm 27.2\end{array}$ & $\begin{array}{l}377.2 \\
\pm 23.2\end{array}$ \\
\hline 㮅 & 反対側 & $\begin{array}{l}17.2 \\
\pm 4.8\end{array}$ & $\begin{array}{l}49.6 \\
\pm 11.6\end{array}$ & $\begin{array}{l}65.2 \\
\pm 3.6\end{array}$ & $\begin{array}{l}107.2 \\
\pm 25.2\end{array}$ & $\begin{array}{l}128.8 \\
\pm 18.4\end{array}$ & $\begin{array}{l}171.2 \\
\pm 15.6\end{array}$ & $\begin{array}{l}230 \\
\pm 14.8\end{array}$ & $\begin{array}{l}257.2 \\
\pm 10.8\end{array}$ & $\begin{array}{l}316 \\
\pm 25.6\end{array}$ & $\begin{array}{l}368 \\
\pm 24\end{array}$ \\
\hline
\end{tabular}

(単位 $\mathrm{msec}$ )

\section{III. 実験結果および考察}

\section{1. 健常者群の成績}

得られた SEP は同一個体では刺激部位と刺激の強さ を変えても基本的波形には变化がなく，また個体間にお いてもかなり類似している．波形は，まず $20 \mathrm{msec}$ 内外 に立ち上がりの鋭い, 小さな陽性頂点, 次いで $50 \mathrm{msec}$
に陰性頂点が認められ，以後陽性と陰性の頂点が交互に 観察された。この波形の成分を便宜上，はじめの陽性頂 点を $\mathrm{P}_{1}$, これに続く陰性頂点を $\mathrm{N}_{1}$ とし, 頂点を順次 $\mathrm{P}_{2}, \mathrm{~N}_{2}, \cdots \mathrm{N}_{5}$ と命名した (図 2).

各頂点の出現率は75〜100\%で，特に $\mathrm{P}_{3}, \mathrm{~N}_{3}, \mathrm{P}_{4}$ での それが高い(表 1 ).

各頂点の潜時は $\mathrm{P}_{1} か ゙$ 18〜25 msec, $\mathrm{N}_{1}$ が50 $56 \mathrm{msec,}$ 以下表 2 に示すごとくである．刺激の強さと頂点潜時を 
表 5 刺激側と反対側 SEP の頂点間の振幅（電位差）(1/8 $\mathrm{g}$ 刺激時）

\begin{tabular}{c|c|c|c|c|c|c|c|c|c}
\hline & $\mathrm{P}_{1}-\mathrm{N}_{1}$ & $\mathrm{~N}_{1}-\mathrm{P}_{2}$ & $\mathrm{P}_{2}-\mathrm{N}_{2}$ & $\mathrm{~N}_{2}-\mathrm{P}_{3}$ & $\mathrm{P}_{3}-\mathrm{N}_{3}$ & $\mathrm{~N}_{3}-\mathrm{P}_{4}$ & $\mathrm{P}_{4}-\mathrm{N}_{4}$ & $\mathrm{~N}_{4}-\mathrm{P}_{5}$ & $\mathrm{P}_{5}-\mathrm{N}_{5}$ \\
\hline $\begin{array}{c}\text { 刺激㑡 } \\
\text { 反EP }\end{array}$ & $5.9 \pm 1.7$ & $7.9 \pm 4.2$ & $9.0 \pm 4.1$ & $8.1 \pm 2.8$ & $12.5 \pm 3.8$ & $16.8 \pm 5.8$ & $4.2 \pm 1.1$ & $16.2 \pm 6.2$ & $20.1 \pm 6.5$ \\
$\begin{array}{c}\text { 反対㑡 } \\
\mathrm{SEP}\end{array}$ & $5.7 \pm 1.3$ & $10.7 \pm 3.9$ & $9.9 \pm 6.3$ & $8.7 \pm 3.4$ & $15 \pm 5.6$ & $21 \pm 3.8$ & $5.1 \pm 1.5$ & $13.2 \pm 3.4$ & $17.3 \pm 6.5$ \\
\hline
\end{tabular}

(単位 $\mu \mathrm{V}$ )

対比させると $\mathrm{P}_{1}$ で $1 / 8 \mathrm{~g}$ では $24.7 \mathrm{msec}, 1 / 2 \mathrm{~g}$ のそれ は $18 \mathrm{ussec}, 2 \mathrm{~g}$ 刺激時で $14.2 \mathrm{msec}$ の結果となり, 刺 激の強さが大きくなるに従って潜時は短くなる。この傾 向は $\mathrm{P}_{1}$ のみならず $\mathrm{N}_{1} \sim \mathrm{N}_{5}$ までの各頂点においてす認 められる.

振幅（電位差）では表 3 に示すごとく，反応の早い成 分 $\mathrm{P}_{1}-\mathrm{N}_{1}$ 間では $1 / 8 \mathrm{~g}$ 刺敫時で $5.7 \mu \mathrm{V}, 1 / 2 \mathrm{~g}$ のそれ は $10.8 \mu \mathrm{V}$ の結果であった。これは刺激の強さが増す ことによって振幅（電位差）が大きくなる傾向を示する のであり， $\mathrm{P}_{1}$ の頂点潜時と同様に反応が刺激の強さに 依存する傾向にあることを示している。，一方，他の頂点 間では $\mathrm{P}_{4}-\mathrm{N}_{4}$ を除いてこのような傾向を認めなかった。 なお，振幅（電位差）の最大值は $\mathrm{N}_{3}-\mathrm{P}_{4}$ で $21 \mu \mathrm{V}$ であ った.

得られた SEP 波形の特致として潜時約 $20 \mathrm{msec}$ の振 幅（電位差）の小さな陽性頂点 $\mathrm{P}_{1}$, それに続く振幅（電 位差）のやや大きな陰性および陽性頂点さらに $180 \mathrm{msec}$ に潜時をもつ立ち上がりの鋭い陰性頂点 $\mathrm{N}_{3}$ と緩く大き な陽性の電位变化である陽性頂点 $\mathrm{P}_{4}$ をあげることがで きる。

また，刺激側と非刺激側の頭皮上から導出した SEP を比較すると両者は互いに類似したものであった。そのの 反応の早い成分 $\mathrm{P}_{1}$ の頂点潜時を比べると非刺激 側で $18.0 \pm 8.4 \mathrm{msec}$, 刺激側で $20.7 \pm 7.9 \mathrm{msec} て ゙ あ り$, 非 刺激側のものが短かった。しかし有意差を認めなかった （表 4)，また，振幅（電位差）についても同様の結果で あった（表 5 ).

なお，得られた反応のらちでモ二ター中の脳波に眼球 運動をはじめとし基線の動摇などのアーチファクトの加 わったもの, 脳波上で覚醒状態にないもの,さらに加算 によっても反応の大きくならないものは分析対象から除 外した。被験部位数と資料数の違いはこの原因によるも のである。

\section{2. 健常者群に対する考察}

得られた波形かＳSEP であるためには，(1 刺激と反応 出現までの潜時が一定であること(2)特定の波形をもつこ とがあげられている゙)。さらに加えれば(3) SEP は加算 に従って波形が成長すること, (4) SEP 成分が刺激の強 さに体存する性質をるつことが考えられる，また，感覚 の種類が異なってもその誘発反応が同しょらな潜時と極
性を有する場合は類似の神経活動にもとづいて生ずるも のである ${ }^{10)}$.SEP に関するこれらの条件についてこれ までの報告とわれわれの得た結果を以下に検討する.

岡ら ${ }^{7)}$ は顔面皮庙の機械的刺激によって潜時 $18.5 \mathrm{msec}$ に陽性頂点を持つSEP が得られ，その出現率は $100 \%$ であったと報告している。また，花森ら゙)は $23.3 \mathrm{msec}$ の陽性頂点を報告している.これらの結果は著者らの研 究で得られた $P_{1}$ と極性および潜時が一致し，またこれ は著者 ${ }^{5)}$ が味覚の誘発反応に関して 報告した舌刺激の SEP と同様の潜時と波形をるつものである.

すでに臨床応用が進んでいる四肢の機械的刺激による SEP とわれわれの得た SEPを比較すると, 解析時間が 同じ場合にはこれらは互いに類似した波形となった。し かし, 初めの陽性頂点 $P_{1}$ の潜時においては，指のそれ

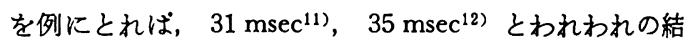
果に比較して延長している。この潜時の差は刺激部位か ら感覚中权までの神経電導距離の長さの違いによって起 こるものと考えられる. 以上からわれわれの得た反応は 機械的刺激に応答した三叉神経領域の SEP と結論し た。

一般的、感覚の強さは刺激の強さに依存するとされ， 両者の間にはべキ関数や対数関数の法則が成り立つこと か知られている，また，刺激に応答する SEP について も Spreng \& Ichioka が歯髄の電気刺激で, Franzen ${ }^{13)}$ が触覚で，㰌ら $\left.{ }^{14}\right)$ が痛覚で刺激量 SEP との振幅（䉓位 差）との間にべキ関数の関保が成り立つことを報告して いる，一方，潜時についても，感覚の反応時間が刺激の 強さに依存することから，振幅（電位差）と同様の関係 を予想することができる，著者は味覚の誘発反応の潜時 が酒石酸濃度との間に

$\mathrm{T}=\mathrm{a} \log \mathrm{b}+\mathrm{C}(\mathrm{a}, \mathrm{C}$ : 定数 $\mathrm{T}$ : 潜時, $\mathrm{b}$ : 濃度) の関係式が成り立ち，味覚誘発反応の潜時は刺激の強さ に依存することを報告しだ)。 以上から，SEP の成分は 刺激量に依存する。すむなわ，SEP は刺激の強さが增 せば振幅（電位差）は增大し，潜時は短縮する性質をす つものである. そこで, 得られた SEP の成分のらちで 刺激の強さに依存するものが感覚の認知に関する中权神 経のプリミティブな活動を示するのであり，かつ他覚的 検査のための指標となるすのと推察する.

そこでわれわれは，SEP 判定の指標として出現率が 
a : 術前

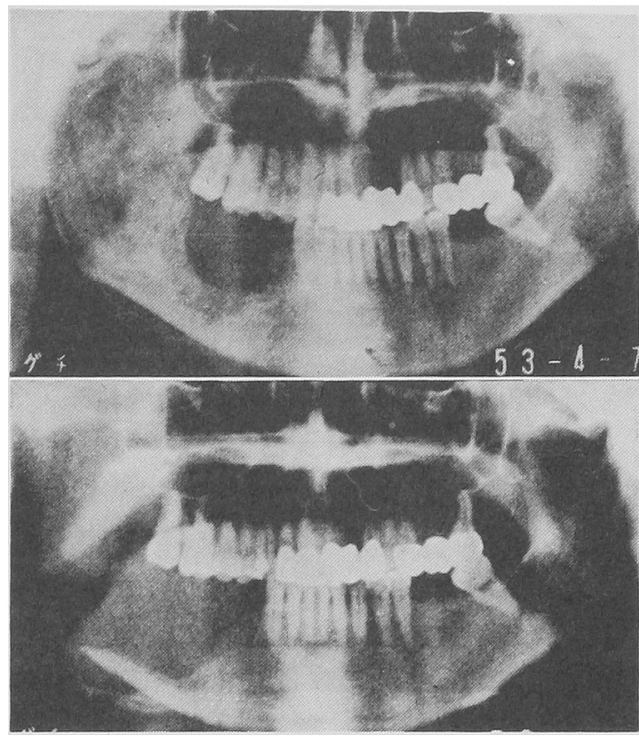

写真 1 症例 1 （29歳, 女性, エナメル上皮腯）のX線像

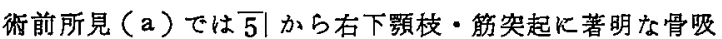

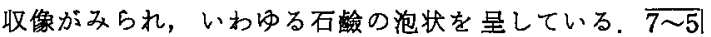
は拔去され，同骨組織は開密察法比より欠損している。

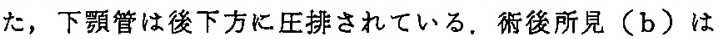
手術による久損像を示す。

高く，特徴のある波形，刺激の強さに相関し，加算効果 が高くから早い反応成分を考えた。本研究で得られた $\mathrm{SEP}$ 成分中では $\mathrm{P}_{1}$ と $\mathrm{N}_{1}$ がこの条件を満足するもので ある、また， $\mathrm{N}_{3}$ は鋭い立ち上がりと大さな電位をるち その形に特致があることから SEP 波形の判別には重要 である，以上の頂点は三叉神経の機械的刺激によるSEP の臨床応用上の重要な指標になるものと考察した。

刺激側の SEP の発生機序は, 神経交差によって反対 側を上行したインパルスが反対側の大脳皮質感覚領に誘 発反応を㟟起し，その反応が corpus callosum を経由し て伝達されたるのである は反対㑡のそれに比して潜時は延長し，振幅（電位差） は小さくなるとされている，しかし，本研究では $P_{1} て ゙$ その傾向がらかがわれたが全体として刺激側の SEP と 非刺激側のそれとの間汇差を認めなかった。

\section{3. 疾患群の成綘}

健常者群と同様の方法で顎骨疾患患者について実験を 行った.

対象は男 3 例，女 4 例の計 7 症例で，年路13〜45歳亦 でである，疾患名はエナィル上皮腫が 3 例，下罘堭胞が 2 例，下顎前突が 1 例，上顎骨骨体骨折が 1 例である。 骨折以外の 6 例はいずれる手術に後遗した神経障害例で ある，これらの症例はすぺて術前と術後に SEP を記録 し，互いに此較・検討した，また，特にエナメル上皮尰 と下影亯胞症例では術前の SEP を非䍜患側あるいは健
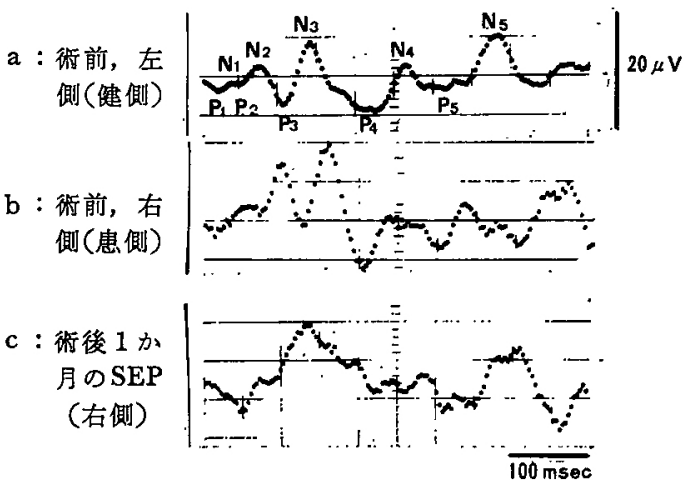

图 3 症例 10 SEP

術前左側（健側）は正常 SEP（a）であるが右側 （患侧）では $P_{1}, N_{1}$ の不明瞭と，潜時の延長を認 める (b). 街後のそれは（c）は不規則な波形で SEP とは認められない。

常者のそれとも比較し，頭骨病変による SEP への影響 についても分析した。

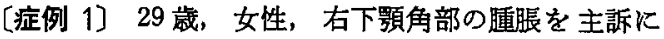
1972 (昭和 47) 年11月来院した。

現病歴：1968（昭和43）年頃より右下頡角部の無痛珄 腫腿を自覚し，某病院にて下䫓桽胞の猃断の下に開空療 法をらけた。 


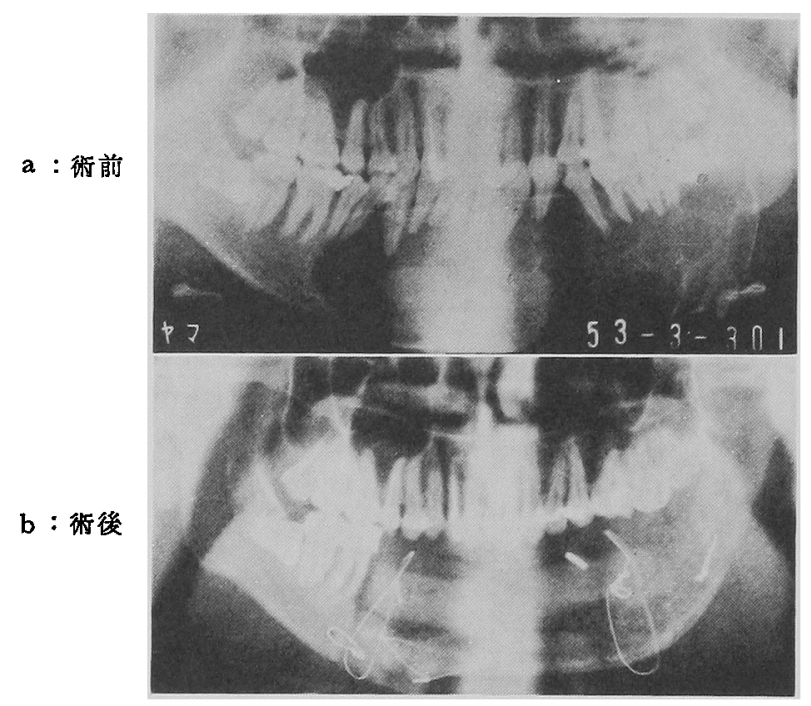

写真 2 症例 2 (19歳, 男性, エナメル上皮腫) のX線像 得前のX線像では $\overline{5+8} に 及 ふ$ 及広沉な骨吸収像と骨膨隆像，左

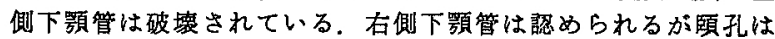

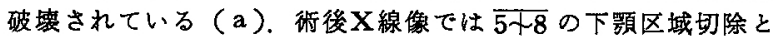
骨移植を示す (b).

$\mathrm{a}:$ 術前, 左 側の SEP
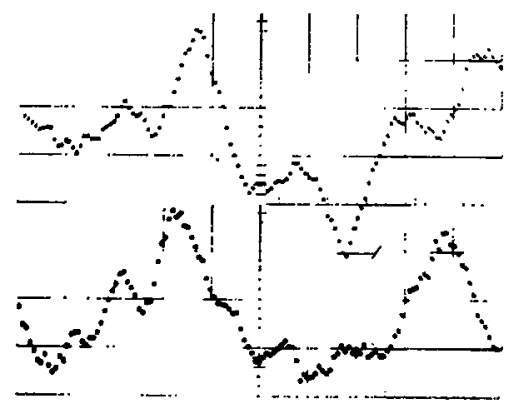

$\mathrm{b} ：$ 谊前, 右 側の SEP
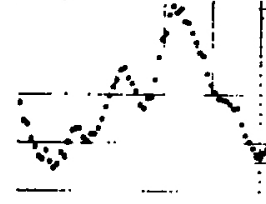

$c:$ 征 後の
SEP

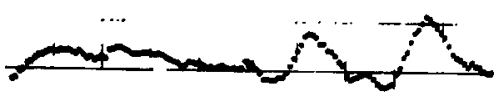

图 4 症例 2 SEP 所見

街前の左側 (a) は早い成分がやゃ不明膫で $P_{1}$ は $56 \mathrm{msec}$ と延長している。右㑡（b）は基線の勤 搯を認めるが各項点はよく区別できる， $P_{1}$ 潜時は $36 \mathrm{msec}$ である。很徯のそれ（c）岋平坦化し，誘 発反応とは認められない。

現 症：右下影骨骨体部から下顎角部にかけて $60 \times$ $65 \times 25 \mathrm{~mm}$ の骨棣硬，無痛性の尰脹が認められた。な お，右下齿槽神経支配頋域の感覚障害を認めなかった。 X線所見ではでより下影枝，能突起におよら゙著明な骨 吸収像があり，いわゆる石踰の泡状所見が認められ，ま
た右側の下䫇管は病変によって後・下方に圧排されてい る(写真1-a).

処置および経過：試験切除材料よりェナィル上皮腫と 病理組織学的飞診断され，次いで可相当部より遠心側 の下顎切除術が施行された（写真1-b)，術直後より， 右下唇の感覚は脱失し，その後 2 か月を経ても感覚障害 回復の兆候は認められなかった。

SEP 所見：健側の SEP は健常者のそれと同棣の波形 を示している（図3-a），一方，衍前の患側 SEP では， $P_{1}$ の頂点が不明瞭で $N_{1}$ の潜時は $104 \mathrm{msec}$ と延長し, 以下 $\mathrm{N}_{3}$ までの各頂点にも潜時が延長している(图 3-b) が認められる。術後 2 か月目の SEP 所見で性不規則な 波形を呈し（图 3-c），刺激に応答した誘発反応とは認 められなかった。 したがって, SEP 上で感覚の脱失が 予想され，自覚的応答に対応寸る結果となった。

〔症例 2】19歳, 男性, 阻徱および審美障害を主訴に 来院.

現病歴：13 歳時に| $\overline{\mathrm{PM}}$ 部の腫脹にきつき，近医にて エナメル上皮尰の診断の下に数度の開空療法を受けたが 改善を得なかった。

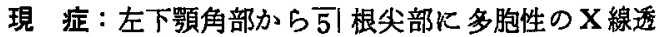
過像および骨膨隆像が観察され，左側の下䫇管は明らか

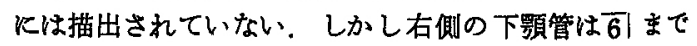
形態を保っている，また，根尖の吸収は $2 \uparrow 7$ に認めら れる (写真 2-a). 願神経領域汇は感覚障害を認めなか った. 
処置および経過：エナメル上皮腫の診断の下に下顎骨 区域切除括よび腸骨移植による下顎骨即時再建術が施行 された（写真 2-b)．下畨槽神経は両側とも骨断端部で 切離された。 したがって, 術後は同神経支配領域に感覚 の脱失が認められた。

SEP 所見（図 4)：術前の SEP は正常群のそれと類 似した波形をしている。しかし，頂点 $\mathrm{P}_{1}$ の不明膫化と それ以降の各頂点潜時の延長が顕著で，主病変のある左 側の $P_{1}$ は健常者の倍にあたる $56 \mathrm{msec}$ ，右側は $36 \mathrm{msec}$ である.このことから神経組織に接する病変の大きさが 增す活ど神経伝導に与える影響は大きくなることが示唆 される、術後1か月目のSEPは，術前のそれとは明ら かに異なり，平担化と不規則な波形となっている，した がって，触刺激による反応とは認められなかった。

〔症例 3] 35歳, 男性, 下顎曰歯部からの排膿を主訴

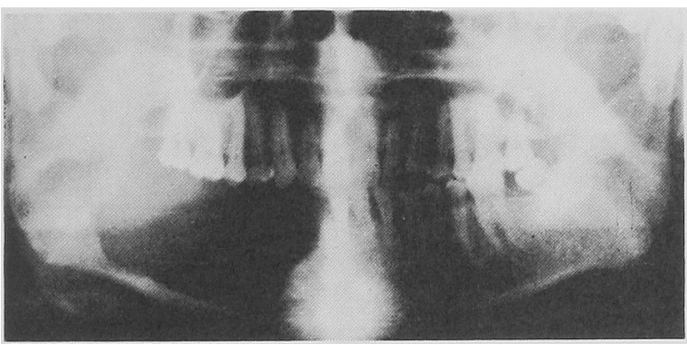

写真 3 症例 3 (35歳, 男性, エナメル上皮腫)の 街後 $\mathbf{X}$ 線像

$\overline{2} \mid$ から $\overline{8} \mid$ 遠心部の骨欠損が認められる。
に来院.

現 症：右䫇下部のびまん性腫脹が認められた。右下 歯槽神経領域の感覚障害を認めなかった，X線像では $\overline{8 \sim 2} \mid$ に骨透過像が観察された。

処置および経過：エナメル上皮腫の診断の下に $\overline{8 \sim 2}$ 部下䫇部分切除が実施された（写真了）。手術時に下歯 槽神経は保存されたが，手術操作中に過って一部を損傷 した，そのため，術直後は感覚の脱失が認められた。 し
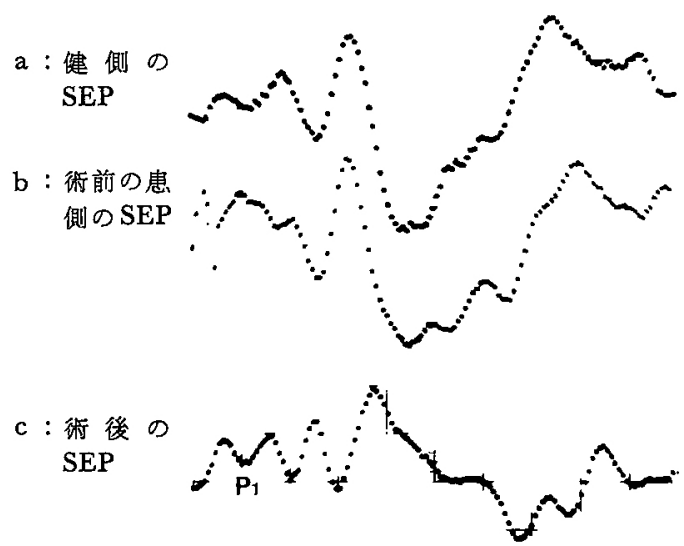

图 5 症例 3 の SEP 所見

路前の健側（a）忙正常波形，路前患側（b) 波形 は正常であるが $P_{2} ， N_{2}$ の波形がやや乱れている。 原後 SEP (c) は $\mathrm{N}_{0}$ の出現と各頂点潜時の遅延を 琶める。

a：䡓前

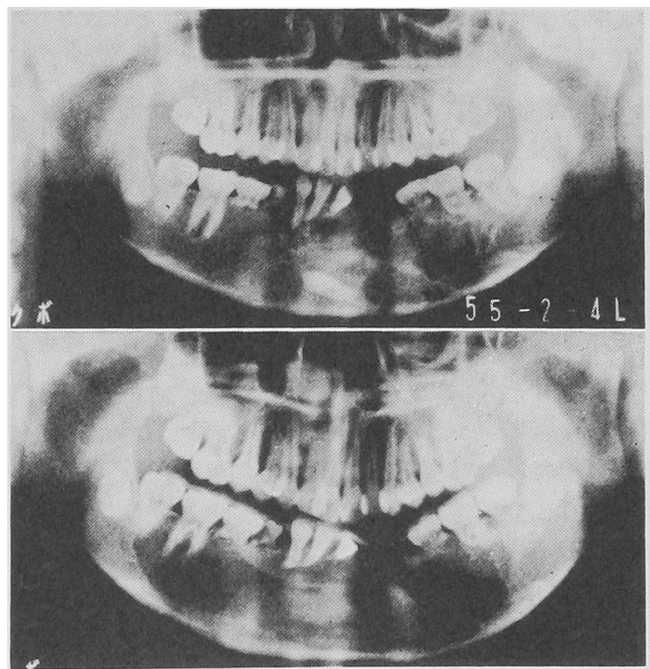

写怘 4 症例 4 (13歳, 女性, 下罘軎胞) のX楾像

$\overline{\mathrm{ED} \backslash \mathrm{E}}$ の晩期残存， $\sqrt{3}$ の埋伏 $\overline{54 \mid 1245}$ の先天欠損があり， $\overline{7 \ngtr 7}$ にX線透過像と一部に蜂巣状を認める。左側願孔は不明 瞭，両側下顎管は下方に王排されている（a）. 開密療法後の $\mathbf{X}$ 線像 (b). 
a : 政前, 左 㑡の SEP

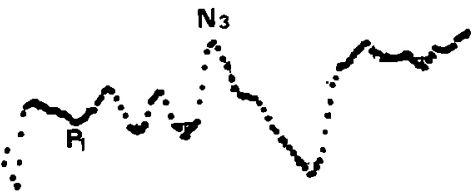

b : 行後, 右 側の SEP

(感覚釷

麻)

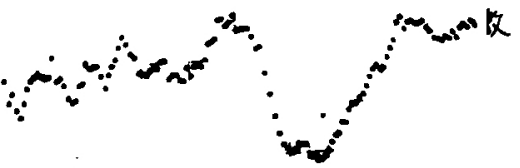

c : 術後, 左 側の SEP

(感覚脱

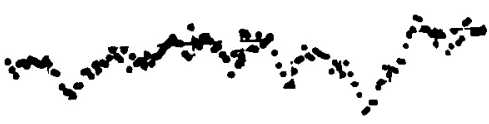

图 6 症例 4 の SEP 所見

衙前の左側 (a) では $P_{1}$ 潜時の延長があり，それ に伴って各頂点とも遇れている，循後の右溉（b) では SEP は不規則となり，感覚脱出の左側（c） はSEP と認められない $\mathrm{a}:$ 很前の

SEP

右㑡（健

側）刺激

b：術前の

SEP

左㑡（患

側) 刺教

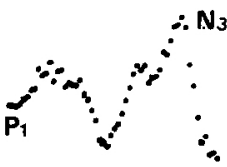

$\mathrm{N}_{3}$

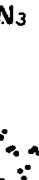

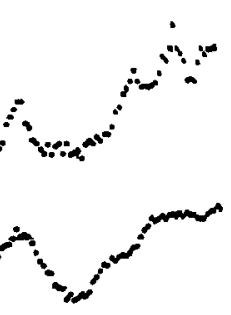

c : 得後の

SEP
左側刺激

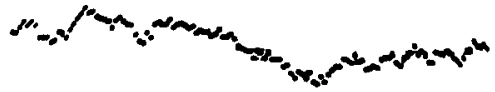

因 7 症例 5 の SEP 所見

術前左㑡 (b) 生 $P_{1}$ と $N_{3}$ を認めるすのの, 右側 (a) にみられる $\mathrm{N}_{1}, \mathrm{P}_{2}, \mathrm{~N}_{2}, \mathrm{P}_{3}$ がみられない. 後のそれ（c）は不規則で誘発反応とは䍿められな い.

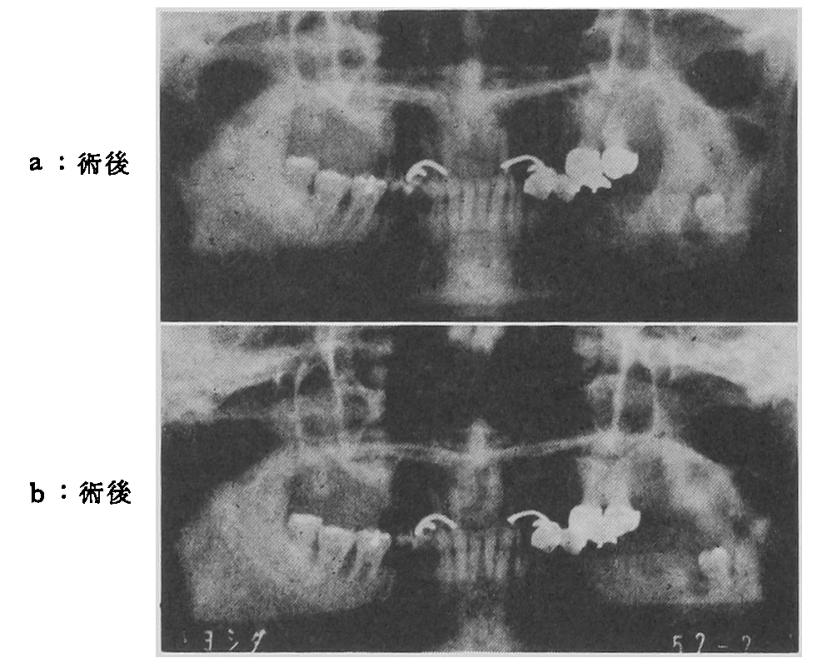

写入 5 症例 5 （45藏，男性，下額胞）のX線像

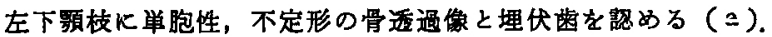
開空渗法後のX線像 (b).

かし，術後 3 週目より自覚症状は余々飞改善し，術挠 4 週目の SEP 記録時には中等度の感覚障害にまて回復し た.

SEP 所見（图 5)：術前のSEP では両僋とも正常の それであった。 しかし，患側では， $\mathrm{P}_{2}, \mathrm{~N}_{2}$ の波形に乱 れがある. 術後 4 週目のSEP は $N_{0}$ の出現， $P_{1}$ (56 $\mathrm{msec}), \mathrm{N}_{1}(92 \mathrm{msec}), \mathrm{P}_{2}(112 \mathrm{msec}), \mathrm{N}_{2}(140 \mathrm{msec})$ の頂点潜時の延長が著明である.

[症例 4] 13葴,女性,左下額部の腫镺を主聆に来院.

現 症 : 頡部にびまん性・無痛性・弾性硬の腫脹が㸾
められた。 X線所見では $\overline{\mathrm{ED} \mid \mathrm{E}}$ の晚期残存と後継永久

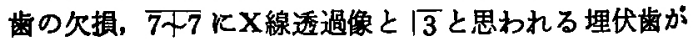
鼠められ，その一部は蜂巣状を呈していた. 左側下靧管 は原より前方では不明瞙である。 また，右側の願孔は 明示されている (写而 4-a). 願神経領域の感覚異常仕 玨められなかった。

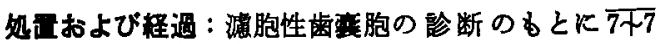
部の開空痖法を実施した（写市 4-b). 術中に下歯槽神 经恃両側とす障害され，術後 1 か月目の SEP 検查時点 でも左側は感覚の脱失が，右側では感覚鈍麻がみられ 


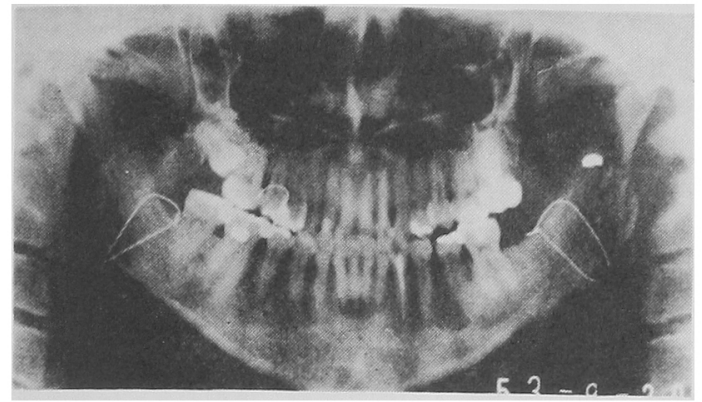

写真 6 症例 6 (25藏，女性，巨買症）のX線像 下顎枝矢状分割咬合改善街街後

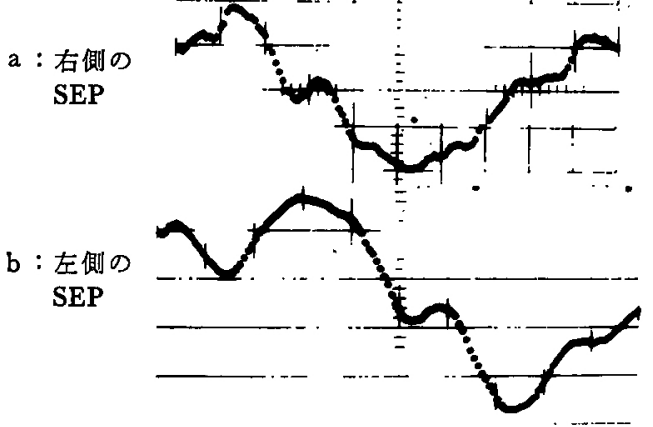

図 8 症例 6 の術後 SEP 所見

右側（a）では基線の動摇を認めるが正常 SEP に 類败している。一方, 左側 (b) は早い成分 (頂点) が明らかでなく，SEPとは言い難い。

た.

SEP 所見（図 6): 術前の左下唇汃らの SEP は $\mathrm{P}_{1}$ 潜 時の延長とそれに伴って各頂点潜時も遅延している. 術 後1か月の SEP では, 右側（鈍麻側）は波形が不規則 となり，左側（感覚脱失側）のそれは平担化しており SEP とは認めがたい.

【症例 5〕 45 歳, 男性, $\sqrt{8}$ 部歯肉の尰脹を主訴に来 院.

現 症：X線像では，左下顎枝に埋伏歯を含んた単胞 性のX線透過性病变が認められた（写真 5-a）。左下齿 槽神経領域の感覚検査では異常を認めなかった。

処置および経過：滤胞性歯菱胞の診断のもとに開空療 法が実施された（写真 5-b）。左側下歯槽神経は，手術 中の操作によって障害され感覚は脱失した。

SEP 所見 (図7)：術前の患側の SEP では $P_{1}$ と $N_{3}$ は明瞭であるが， $\mathrm{N}_{1} ， \mathrm{P}_{2}, \mathrm{~N}_{2}, \mathrm{P}_{3}$ の頂点が明らかでな い. また，術後 2 週目のそれは平担化し，SEP とは言 い難い所見を示している。

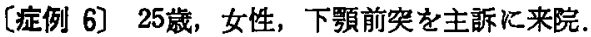

処是および経遇：下影枝矢状分割咬合改善術を施行さ れた（写事 6) が，術後に両側の願神経領域に感覚鈍麻

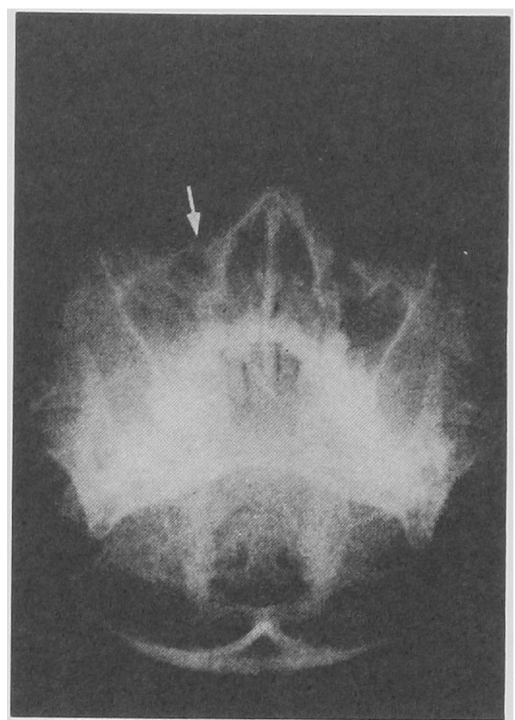

写真 7 症例 7 (30歳，女性，上顎骨 骨折) DX線像

右眼简下緑（矢レ゙）で骨折を認める。

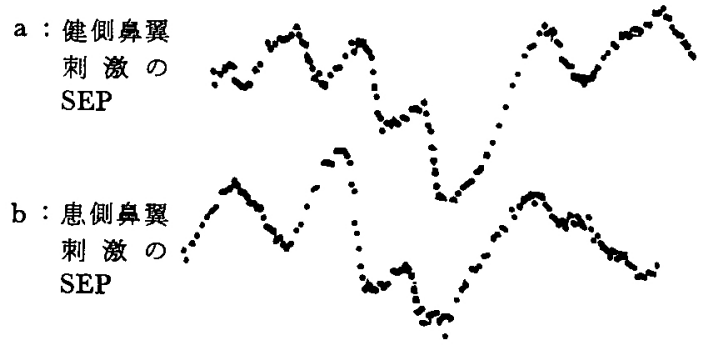

图 9. 症例 7 のPE 所見

健㑡算の刺激では下层部刺類似した波形( a ), 患側のそれで仕 $P_{1}, N_{1}$ に相当する頂点が明らかて ない（b).

が発症した．自覚的応答では左側が右側よりも障害の程 度は大であった。

SEP 所見（図 8）：健常者のそれと比較すると，基線 の動摇が著しい，右側では健常者の SEP との類似性を 認めるが変形したるのである，さらに，左側のそれは波 形の乱れは著しくSEP とはいいがたい。

〔症例 7〕 30歳, 女性, 顔面・奥部の感覚障害を主訴 に来院.

現病歴・現 症：スキー滑走中に崖より転落した。右 眼窝下縁に骨折によると思われる楩没があり，右販窝下 神経支配領域では温・冷および痛覚の脱失々触覚の鈍麻 が羿められた．X線所見では右眼窝下縁に骨折線が認め られた（写而 7)。

SEP 所見 (图9):本症例では左右の量翼部に刺激を 
あたえ，反応を誘発した，健側の SEP は潜時の延長を 認めるが下唇部刺激のそれと同様の波形を示している. 一方，患側のそれは $1 / 8 \mathrm{~g} ， 1 / 16 \mathrm{~g}$ 刺激ともに $\mathrm{P}_{1}$ を認 められない。しかし， $1 / 2 \mathrm{~g}$ では $\mathrm{N}_{1}$ 以降の波形は健側 のそれに類似している。

以上の結果から，本研究に拈ける疾患症例群から得ら れた SEP 所見として，

1) SEP 波形が明瞭で潜時に異常を認めない場合に は感覚に異常がない:

2 ）感覚障害のない場合においても腫瘍や㘍胞などの 病変の存在によって SEP 潜時や波形の不明瞭化などの 所見がみられる。

3 ）感覚障害では SEP に異常所見が認められ，障害 の程度が強いものほどSEP の異常はより顕著となり， 感覚脱失では SEP は平坦となり誘発反応とは認められ なくなるの三点に要約される.

\section{4. 疾患群に対する考察}

SEP の異常として黒岩ら ${ }^{16)}$ は SEP 全成分の低電位 あるいは欠如, 高振幅, 不規則な波形, 各成分の部分的 欠如あるいは異常をあげている，また，島田 ${ }^{12)}$ は末梢神 経障害の SEP の特徽として潜時の延長さらに感覚障害 の強い例ではSEP は記録できなかったと述べている.

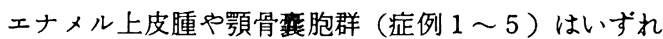

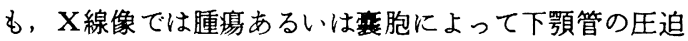
や偏位を認めたものの, 自覚的には感覚異常の訴えはみ られなかった。エナメル上皮腫や壤胞などの良性あるい は相対的に非浸潤性の病変では神経や血管組織をはじめ とする病変周囲組織への直接的な破壊を起こすことが比 較的少ない，そのため，たとえば症例 2 のごとく骨破壊 の著しい場合でも自覚的には神経障害の所見を認めるこ とはないと従来いわれている。しかし，本研究の結果で は，感覚刺激に対してはほほ正常な自覚的応答を示しな からら, 症例 $1 \sim 5$ においては術前の SEP に $P_{1}$ 潜時 の延長が，さらに症例 3 では SEP 全体の波形の乱れが みられ，健側のそれとは異なった所見を示すなと SEP に異常所見を認めた。

また，頂点潜時の遅延例においても症例 2 のごとく骨 破壊の重篤な左側の $\mathrm{P}_{1}$ が $56 \mathrm{msec}$, 軽い右側では $36 \mathrm{msec}$ となり, 病変の進行している側での頂点潜時の遅延が目 立った.

このことから本研究の術前 SEP 群においては, 神経 組織に接する病変の大きさが増すほど SEP に与える影 響は大きいことが示唆された。

反応時間は刺激を加えてから刺激を認知するまでに要 した時間を示すものであり，神経伝導と刺激認知に関す る有力な指標である. Eason ら ${ }^{17)}$ は反応時間が長くなれ ば誘発反応の潜時も延長することを視覚の研究で明らか にした. Melzack \& Wall18)は感覚の反応時間に関して, 正常の求心性入力を歪めるものとして，(1) 種々の太さ
の神経線維群間にみられる相対的活動度，（2）伝道遮断 帯を伝達されるインパルスの最大頻度，（3）活動線維の 数，（4）自発的に進行している活動，(5) 末梢終末器に おけるェネルギー変換性の 5 因子をあげている。さら に, Giblin 5 ${ }^{19)}$ は末梢神経障害による感覚神経伝導速 度の遅延が SEP の頂点潜時に反映するとしている，こ の点に関して，反応時間が SEP の潜時と同質のものと 考えることはできないが, Melzack \& Wall の仮説によ って SEP 異常発現のメカニズムは理解されよう。すな わち，腫場や襄胞による神経線維の圧迫あるいは腫湯細 胞から産生される化学物質が神経活動—ーンパルスの 頻度, 強さ, 時間的・空間的パターン一に歪みを生じ させ，各神経線維間に后導時間の不均一と反応の非同期 化が生ずる，そしてその影響は病変と神経組織との係わ りが大きくなるほど強くなるものであろう。その結果と して SEP は波形の異常や頂点潜時（特に $\mathrm{P}_{1}$ ）に遅延を きたするのと推察される。

以上, SEP は, 自覚的には感覚異常が表出されない 時期においてすでに，神経厷導の異常を明らかにしらる ことを示し，本法の臨床応用上の重要な点である.

術後神経伝導障害例の SEP では前述した異常所見の いずれかが認められた。すなわち感覚脱失の症例 $1 ， 2$, 4 (左側)，5，ではいずれもが平担化し，刺激に応答す る反応とは認められず, 一方, 感覚鈍麻の症例 3，4 (右 側)，6，7 の SEP では頂点潜時の遅れ，波形の乱れ， 頂点の不明瞭などの所見がみられた。しかし，鈍麻症例 の SEP は基本的には健常者の SEP とよく類似したも のであった。

感覚脱失例はいずれも手術時に下歯槽神経を切断した 症例あるいは手術操作中搔爬によって強く神経を損傷し たものであり, 誘発反応が得られないのは当然と思われ る.

皮店の感覚は重なりあった神経線維網による多重神経 支配を受けており，刺激によって発生したインパルスは べつべつの神経伝導路を脳に向かって上行する，そのた め, 本研究の感覚障害群のごとく层導路（神経束である 下歯槽神経）に損傷が起こった場合，終末部では正常の インパルスが発生したとしても，障害された神経線維の 支配する領域とその数によって中权神経に送られるイン パルスはその影響を受ける。ささらに，このインパルスは 神経伝導路にあるニューロンやシナプスなどの神経細胞 あるいは大脳皮質で時間的に加重される，そのため反応 を導出した場合には，感覚鈍麻应例のような一定程度の 伝導障害でも非同期化した信号が神経細胞の働きによっ て正常の SEP に近い波形を生み出し，また重症な伝導 障害においても SEP を記録できたものと考えられる. なお，その際の SEP の潜時は Giblin の指摘のごとく 神経伝導障害によって明らかに延長するものであろら.

ここで問題となるのは，感覚鈍麻症例では潜時の遅延 
や波形の乱れが認められたが，この所見は必ずしも感覚 障害のみにみられるものではなく，すでに術前 SEP で 述べたごとく自覚的には感覚障害がなくても腫韵や慗胞 の存在によって誘発反応上に潜時の延長や波形の乱れな どが観察されていることである。本研究ではSEP の異 常が感覚異常を起こしているか否かを明らかにすること はできず, 感覚障害の程度を SEP によって数量化する ことと共に今後の課題として残された.

\section{IV. ま と め}

健常者群と顎骨病変患者群に対して三叉神経領域（下 歯槽神経）を主とする機械的刺激による体性感覚誘発反 応 (SEP) を記録・分析し，以下の結果を得た。

1. 健常者の $1 / 2 \mathrm{~g}$ 刺激時の SEP では初めの小さな 陽性頂点 $\mathrm{P}_{1}(18 \pm 8.4 \mathrm{msec})$ これに続く陰性頂点 $\mathrm{N}_{1}$ $(56.2 \pm 7.4 \mathrm{msec})$ 以下 $\mathrm{P}_{2}(80 \pm 14 \mathrm{msec}), \mathrm{N}_{2}(112.2 \pm$ $16.5 \mathrm{msec}), \quad \mathrm{P}_{3}(135.2 \pm 20.6 \mathrm{msec}), \quad \mathrm{N}_{3}(174.4 \pm 21$ $\mathrm{msec}), \mathrm{P}_{4}(242.6 \pm 21.6 \mathrm{msec}), \mathrm{N}_{4}(285.3 \pm 23.2 \mathrm{msec})$, $P_{5}(333.6 \pm 19.8 \mathrm{msec}), N_{5}(398.9 \pm 32.1 \mathrm{msec})$ が交互 に認められた。

2. $\mathrm{P}_{1}$ では $1 / 8 \mathrm{~g}, 1 / 2 \mathrm{~g}, 2 \mathrm{~g}$ と刺激を強くするに従っ て頂点の潜時が短くなる傾向を示した。

3. SEP 波形が明瞭で潜時に異常を認めない場合には 感覚に異常を訴えていない.

4. 感覚障害のない場合においても腫場や露胞などの 病変の存在によって SEP 潜時の遅延（特に $\mathrm{P}_{1}$ ) や波形 の不規則などの所見がみられる。この場合, 病変は神経 云導に影響を及ぼしているものと考えられる。

5. 感覚障害ではSEP に異常所見が認められ，障害の 程度が強いものでは SEP の異常は顕著となり, 感覚脱 失では平坦となり誘発反応とは認められなくなる。

これらの結果をまとめると，SEP の波形，特に $\mathrm{P}_{1}$ 頂 点の波形と潜時は感覚の有無あるいは病变の神経線維へ の影響についての指標となる。 また, 神経伝導障害の存 在をSEP によって明瞭に示すことができたが，障害の 量的そして質的变化としての感覚異常を必ずしも明らか に表示するとは限らず，今後の課題として残されてい る.しかし，これはSEP の有用性を否定するものでは なく，全体を総括すれば本検索法が三叉神経領域の他覚 的検査法の 1 つして臨床的意義を見い出すものであ る.

本研究は東京医科菌科大学第 1 口腔外科学教室に招い て行ったものであり, 塩田重利教授, 浜松医大茂木克俊 教授ならびに被験者としてこ協力いたたいた東京医科菌 科大学第 1 口腔外科学教室の先生方に感謝いたします。

なお，本研究の一部は第32回口腔科学会総会(1978年) にて講演した。
本研究は文部省科学研究費の援助によるものである。

\section{引用 文 献}

1) Spreng, M. and Ichioka, M.: Langsame Rindenpotentiale bei Schmerzreizung der Menschen. Pflugers. Arch Ges Physiol 279: 1211321964.

2) Chatrian, G.E., Canfield, R.C., et al.: Cerebral responses to electrical tooth stimulation in man. Neurology 25: 745-757 1975.

3）藤本洋, 堀田文雄, 他: 㐘の電気刺激に上る 頭皮上誘発電位と八リ麻酔。臨床脳波 18: 3994071976.

4）佐野晴雄：㐘牙電気刺激に上る体性感覚譑発電 位におよほす刺激強度と30\%笑気吸入との影響 について。畦麻誌 5：9-21 1977.

5）柳澤繁孝: 味覚誘発反応の臨床応用に関する研 究. 口病誌 47: 526-540 1980 .

6) 花森隆充, 村山伸樹, 他 : 七上の指と舌の触誘 発反応。日生理誌 39：92 1977 .

7）岡 信男, 末吉貫爾, 他：三叉神経領域の機械 的刺激に上る体性感覚誘発電位について。臨床 脳波 21: 751-757 1979.

8）藤森聞一, 佐藤時治郎, 他: 脳の電気現象の分 析法とその応用. 医学書院, 東京, 1979, 271282 頁.

9) 大西信治郎, 真鍋敏毅: ERA一他覚的聴覚検査 の手引き。金芳堂, 京都, 1976, 13頁.

10) Goff, W.R., Matsumiya, T., et al.: Crossmodality comparisions of averaged evoked potentials. NASA sp 191: 95-141 1969.

11) Nakanishi, T., Takita, K., et al.. Somatosensory evoked responses to tactile tap in man. Electroenceph. clin Neurophysiol 34: 1-6 1973.

12）島田康夫：機械的刺激に上る体性感覚誘発電 位. 臨床神経 14: 728-737 1974.

13）槅直矢, 豊岡秀訓, 他: 体性感覚譑発反応と 針麻酔。臨床脳波 16: 432-437 1974 .

14) Franzen, O. and Offenloch, K.: Evoked response correlates of psycophsical magnitude estimates for tactile stimulation in man. Exp Brain Res 8: 1-18 1969.

15）田村潔：刺激と同側の大脳皮質に扣ける体性 感覚誘発反応成する研究. 臨床神経学 12: 553-561 1972.

16）黒岩義五郎, 加藤元博：大脳誘発電位とその臨 床的応用。神経進歩 12：437-447 1968 .

17) Eason, R.G., Oden, D., et al.: Visually evoked cortical potentials and reaction time in relation to site of retinal stimulation. Electroenceph. clin. Neurophysiol 22: 313-324 1967.

18) Melzack, R. and Wall, P.D.: On the nature of cutaneous sensory mechanisms, Brain 85: 331-356 1962. 市岡正道訳: 皮虐感覚. 東京, 
医料薬出版, 1969, 289頁. (Sinclair, D.: Cutaneous Sensation. London, Oxford Univ Press, 1967. ) より引用.

19) Giblin, D.R.: Somatosensory evoked potentials in helathy subjectives and in patients with lesions of the nervous system. Ann NY Acad Sci 12: 93-141 1964. 